\title{
Empirical indicators of the level of stress resistance in students of humanitarian and technical specialties
}

\author{
Litvinova O., Fedorenko S. \\ Kremenchuk Mikhailo Ostrogradskyi National University, Kremenchuk, Ukraine
}

Received: $17.04 .2019 \quad$ Accepted: 26.04 .2019

\begin{abstract}
The article substantiates the theoretical and methodological foundations of the study of the problem of stress resistance of students of humanitarian and technical areas of study. The relevance of studying this problem in the conditions of students experiencing adaptive, informational, examination stress is shown. It is emphasized that the experience of chronic stress is caused by the general situations of uncertainty of the entire Ukrainian society associated with the unstable political, economic situation, as well as military actions in the east of our state. Analyzed theoretical approaches to the study of the category of "stress tolerance", "adaptability", "coping strategies" in domestic and foreign psychology. An empirical study of the level of development of stress resistance indicators (coping strategies, neuropsychic stability, adaptability to stress) was carried out for students of humanitarian and technical specialties with the help of reliable and valid psychodiagnostic tools. It is shown that students of the humanities profile have lower rates of neuropsychic resistance, less pronounced adaptability to stressful situations, compared to students of technical specialties. The differences in the choice of coping strategies by students of various specialties are revealed. It was stated that students of technical specialties are mostly characterized by the use of avoidance, distraction and social distraction as a coping strategy. Humanities students choose emotionallyoriented strategies to cope with stressful situations, and this is due to the active external manifestation of emotions, the desire to get support from others. It was determined that such differences may be associated with gender characteristics of students of these specialties, on the one hand, and on the other, with objects of future professional activity (people or technicians). These circumstances impose a large emotional burden associated with working with people on the humanitarian specialist. It was stated that problem-oriented coping has low rates for students of humanitarian specialties, and technical ones. This fact should be taken into account when developing a program of psycho-correctional work, as the ability to analyze the causes of stressful situations, planning ways to overcome them is an indicator of a socially mature personality. Emphasis is placed on the need for psychological correction and psychological support for students during their studies at the university to increase their stress resistance.
\end{abstract}

Key words: stress resistance, coping strategies, student age, neuropsychic stability, adaptability, professional orientation.

\section{Емпіричні показники рівню стресостійкості у студентів гуманітарних та технічних напрямів навчання}

\author{
Літвінова О. В., Федоренко С. А.
}

Кременчуцький національний університет імені Михайла Остроградського, Кременчук, Україна

\begin{abstract}
Анотація. У статті обґрунтовано теоретико-методологічні засади дослідження проблеми стресостійкості студентів гуманітарних та технічних напрямів навчання. Доведено актуальність вивчення даної проблеми в умовах переживання студентами адаптаційного, інформаційного, екзаменаційного стресів. Зроблено акцент на тому, що переживання хронічних стресів пов'язано із загальною ситуацією невизначеності всього українського простору, обумовленого ситуацією політичної, економічної, соціальної нестабільності та військовими діями на сході нашої держави. Проаналізовано теоретичні підходи до вивчення категорії «стресостійкість», «адаптивність», «копінг-стратегії» у вітчизняній та зарубіжній психологіі. Проведено емпіричне дослідження наявного рівню розвитку показників стресостійкості (копінг-стратегій, нервовопсихічної стійкості, адаптивності до стресу) у студентів гуманітарних та технічних напрямів навчання за
\end{abstract}

\footnotetext{
Corresponding Author: Litvinova Olga Volodymirivna,Tel. +38(050) 913-15-23. E-mail: litvinova1992@gmail.com Kremenchuk Mykhailo Ostrohradskyi National University, vul. Pershotravneva, 20, Kremenchuk, Poltava Region, Ukraine, 39600.

Відповідальний автор: Літвінова Ольга Володимирівна.Тел. +38(050) 913-15-23. E-mail: litvinova1992@gmail.com Кременчуцький національний університет імені Михайла Остроградського, вул. Першотравнева, 20, м. Кременчук Полтавської обл., Україна, 39600.
} 
допомогою валідного та надійного психодіагностичного інструментарію. Визначено, що студенти гуманітарних спеціальностей мають більш низькі показники нервово-психічної стійкості, меншу адаптованість до стресових умов у порівнянні зі студентами технічних спеціальностей. Виявлено відмінності у виборі копінг-стратегій серед студентів різних напрямів навчання. Доведено, що студентам технічних спеціальностей більш притаманно використання таких стратегій подолання як: уникнення, відволікання та соціального відволікання в якості копінг-стратегій, тоді як студенти-гуманітарії обирають емоційно-орієнтований копінг, пов'язаний 3 проявом емоційних реакцій назовні, бажанням отримати підтримку від оточуючих. Визначено, що такі відмінності можуть бути пов'язані, з одного боку, із статевими особливостями студентів даних спеціальностей, а з іншого - із об'єктами майбутньої професійної діяльності (люди чи техніка), що вимагає від спеціалістів гуманітарного профрілю більшого емоційного навантаження, пов'язаного із роботою з людьми. Констатовано, що проблемно-орієнтований копінг має низькі показники прояву у студентів обох напрямів навчання, і це потребує врахування при розробці програми психокорекційних впливів, адже аналіз причин виникнення стресових ситуацій та планування шляхів їх подолання $€$ показником соціально зрілої особистості. Наголошено на необхідності впровадження в систему підготовку фахівців різного профілю навчання психологічної складової, в процесі якої студенти отримують необхідні знання та навички щодо розвитку стресостійкості.

Ключові слова: стресостійкість, копінг-стратегії, студентський вік, нервово-психічна стійкість, адаптованість, професійна спрямованість.

\title{
Эмпирические показатели уровня стрессоустойчивости у студентов гуманитарных и технических спеціальностей
}

\author{
Литвинова О. В., Федоренко С. А. \\ Кременчугский национальный университет имени Михаила Остроградского, Кременчуг, Украина
}

\begin{abstract}
Аннотация. В статье обоснованы теоретико-методологические основы исследования проблемы стрессоустойчивости студентов гуманитарных и технических направлений обучения. Показана актуальность изучения данной проблемы в условиях переживания студентами адаптационного, информационного, экзаменационного стрессов. Сделан акцент та том, что переживание хронических стрессов обусловлено общей ситуаций неопределенности всего украинского социума, связанного с нестабильной политической, экономической ситуацией, а также военными действиями на востоке нашего государства. Проанализированы теоретические подходы к изучению категории «стрессоустойчивость», «адаптивность», «копинг-стратегии» в отечественной и зарубежной психологии. Проведено эмпирическое исследование уровня развития показателей стрессоустойчивости (копинг-стратегии, нервно-психическая стойкость, адаптивность к стрессу) у студентов гуманитарных и технических специальностей с помощью надежного и валидного психодиагностического инструментария. Показано, что студенты-гуманитарии имеют более низкие показатели нервно-психической стойкости, менее выраженную адаптивность к стрессовым ситуациям, по сравнению со студентами технических специальностей. Выявлены различия в выборе копинг-стратегий студентами различных специальностей. Констатировано, что студентам технических специальностей в большей степени характерно использование избегания, отвлечения и социального отвлечения в качестве копинг-стратегии, тогда как студенты-гуманитарии выбирают эмоционально-ориентированные стратегии преодоления стрессовых ситуаций, что связано с активным внешним проявлением эмоций, стремлением получить поддержку от окружающих. Определено, что такие различия могут быть связаны, с одной стороны, с гендерными особенностями студентов данных специальностей, а с другой - с объектами будущей профессиональной деятельности (люди или техника), что возлагает на специалиста гуманитарного профиля большую эмоциональную нагрузку, связанную с работой с людьми. Констатировано, что проблемноориентированный копинг имеет низкие показатели у студентов обоих направлений, и этот факт необходимо учитывать при разработке программы психокоррекционной работы, так как умение анализировать причины возникновения стрессовых ситуаций, планирование путей их преодоления является показателем социально зрелой личности. Сделан акцент на необходимости проведения психологической коррекции и психологического сопровождения студентов во время обучения в вузе для повышения уровня их стрессоустойчивости.
\end{abstract}

Ключевые слова: стрессоустойчивость, копинг-стратегии, студенческий возраст, нервно-психическая стойкость, адаптивность, профессиональная направленность.

\section{Bcmyn}

На сучасному етапі розвитку системи вищої освіти одним з найважливіших завдань є формування всебічно розвиненої та самодостатньої особистості. Студент володіє великими ресурсами для власного розвитку, поміж яких існує цілий ряд індивідуально-психологічних особливостей, що можуть поставати 
на заваді повноцінного вирішення основних завдань. Серед них особливе місце посідає феномен стресостійкості. Погоджуючись із справедливою думкою, що стрес - це супутник студентського життя, зазначимо, що максимальне загострення багатьох протиріч, які, в свою чергу, провокують найрізноманітніші проблемні ситуації, відбувається саме на початковому етапі студентських років. Навчання у ВН3 - це пора самоаналізу і самооцінок, особистісних виборів і самовизначень. У переліку найважливіших проблем, 3 якими стикаються студенти під час навчання, міститься проблема переживання екзаменаційних стресів. Загалом актуальність проблематики дослідження тісно пов'язана з їі недостатнім рівнем вивчення та відсутністю ґрунтовних аналітичних досліджень, у яких би зосереджувалася увага на проблемі взаємозв'язку стресостійкості студентів та їх навчальною діяльністю.

Другий фактор, згідно якого тематика репрезентованого дослідження сьогодні не втрачає актуальності, обумовлений особливістю сучасного простору - різким розширенням обсягу інформації у житті сучасної людини, а, відтак, виникненням у неї так званого інформаційного стресу. Інформація, яка надходить з масових джерел, у більшості випадків наповнена негативним змістом, викликає підвищене хвилювання та тривожні стани. Студенти - не становлять виключення з правил. У них інформаційний стрес може виникати через тривалу та часто суперечливу інформацію щодо правил складання сесій, змін у положенні про нарахування стипендії, наявності (відсутності) попиту на фахівців обраного професійного спрямування тощо. Внутрішні конфлікти, велике внутрішнє напруження можуть впливати на фізичний стан студента, спричиняючи загострення хронічних захворювань, головний біль, погіршення сну, апетиту тощо, що свідчить про появу типових симптомів стресу.

Проблемі стресостійкості присвячено праці багатьох зарубіжних вчених, зокрема: Д. Амірхана, Д. Грінберга, У. Кеннона, Р. Лазаруса, Л. Мерфі, Г. Сельє, С. Фолькмана та ін. У вітчизняній літературі проблема стресостійкості представлена дослідженнями Л. Аболіна, Б. Ананьєва, Б. Варданяна, Б. Вяткін, А. Глушко, О. Конопкіна, А. Лібіна, А. Реана, Т. Середи, Ю. Щербатих та ін. Утім, необхідність запобігання та профрілактики стресових станів у студентської молоді в контексті реформування системи вищої освіти в Україні потребує додаткового вивчення проблеми стресу та стресостійкості в молоді студентського віку.

\section{II Матеріал і методи дослідження}

Для позначення явища стійкості в психології використовуються такі поняття, як «стійкість до стресу», «стійкість до фрустрації» і т.д. В основі змістового визначення покладено виокремлення різних аспектів складних ситуацій та їхнього впливу на психічну регуляцію поведінки, а точніше кажучи, на діяльність і розвиток особистості. Стійкість до стресу розуміється по-різному: 1) як здатність витримувати інтенсивні або незвичайні стимули, що представляють собою сигнал небезпеки й спричиняють зміни у поведінці; 2) як здатність витримувати надмірне порушення й емоційну напругу, що виникає під впливом стресорів; 3) як здатність витримувати без перешкод для діяльності високий рівень активації.

У психологічному словнику стресостійкість визначається як набір особистісних рис, що визначають стійкість до різних видів стресів. Стресостійкість складається з трьох взаємопов'язаних компонентів: 1) відчуття важливості свого існування; 2) почуття незалежності і здатності впливати на власне життя; 3) відкритості та інтересу до змін, ставлення до них не як до загрози, а як до можливості розвитку [1].

С. В. Суботін під терміном «стресостійкість» розуміє такі його складові, як емоційна стійкість, психологічна стійкість до стресу, стрес-резистентність, фрустраційна толерантність [2].

А.А.Баранов пропонує вважати стресостійкість окремим випадком психічної стійкості, що виявляється при дії стрес-факторів [3]. Б. Х. Варданян визначає стресостійкість як властивість особистості, що забезпечує гармонійну взаємодію між усіма компонентами психічної діяльності в емоціогенній ситуації, що сприяє успішному виконанню діяльності [3].

Студентський вік - це період стрімкого розвитку і швидких змін особистості.

Саме на цьому етапі відбувається становлення юнака як майбутнього фахівця. Студент неминуче стикається з різними труднощами, перебуваючи у вищому навчальному закладі. Ці труднощі можуть спричинятися великою кількістю різноманітних причин, що, 3 одного боку, обумовлюються 
особливостями навчального процесу у ВН3, з іншого - особистісними властивостями студента. У перший рік студентського життя основною причиною стресу можуть бути кардинальні зміни життя молодої людини, перед якою постають нові завдання-виклики: необхідність адаптації на новому місці, до нових правил та норм, до нового середовища і незнайомих для неї людей. Крім цього, відбувається втрата міцності контактів з колишніми однокласниками, зі звичним колом спілкування. Деяким юнакам важко попрощатися з життям відчайдушного школяра, важко усвідомити, що дитинство вже закінчилося. Цей факт нерідко викликає потужний стрес.

Іншою причиною виникнення стресу в житті студента може стати необхідність переїзду до іншого місця проживання, відірваність від батьківського коріння, від домашнього затишку, віддалення від батьків. До вагомих причин можна віднести обмеженість фрінансів або невміння правильно розпоряджатися ними.

Як відомо, студенти, переважно у своїй більшості, ведуть дуже активний спосіб життя. Основний час вони витрачають на навчальний процес, потім - на підготовку до занять, решту - на спілкування 3 друзями і родичами, а також на інші особисті справи. У зв'язку з цим ще однією причиною стресу у студентів можна назвати нерегулярне харчування і недостатню кількість сну, особливо у тих, які проживають у гуртожитку. Серед інших особистісних факторів, що впливають на причини стресу, можна виділити: хворобу або смерть членів сім'ї; конфрлікти з одногрупниками та близькими людьми; переїзд; проблеми у відносинах з протилежною статтю; проблеми зі здоров'ям. До окремої групи причин стресу відносяться шкідливі звички (паління, зловживання алкоголем або іншими психоактивними речовинами).

Особливе місце в житті студента займає стрес, пов'язаний з навчальним процесом. Навчальний стрес - це стан, що характеризується надмірною напругою тіла, зниженням емоційного та інтелектуального потенціалу, що у подальшому породжує психосоматичні захворювання та припинення особистісного зростання студента [4].

До причин навчального стресу можна віднести: невчасно здані або незахищені практичні або лабораторні роботи; невиконані або виконані неправильно завдання; велика кількість пропусків та недостатньо повні знання з будь-якої навчальної дисципліни; погана успішність; занадто велике навчальне навантаження; відсутність зацікавленості до дисципліни або до запропонованої студенту роботи; виникнення конфліктних ситуацій з викладачем; відсутність належного доступу до навчального матеріалу; незадоволеність отриманою оцінкою; розчарування в обраній професії тощо.

До найбільш різко вираженої форми навчального стресу можна віднести екзаменаційний стрес. Екзаменаційний стрес - це одна з форм психічного стресу, яка нерідко обумовлює екзаменаційний невроз і $є$ безсумнівним психотравмуючим фрактором [5].

Дуже часто іспит стає психотравмуючим фактором, на який звертається серйозна увага навіть в клінічній психіатрії під час визначення характеру психогенії і класифікації неврозів. В останні роки дослідниками отримано переконливі докази того, що екзаменаційний стрес негативно впливає на нервову, серцево-судинну та імунну системи студентів. Очікування іспиту і пов'язана з цим психологічна напруга можуть проявлятися у студентів у вигляді різних форм психічної активності: у вигляді страху перед екзаменатором або негативною оцінкою, або у вигляді більш дифузної, мало обґрунтованої невизначеної тривоги через перспективу майбутнього іспиту.

Орієнтуючись на теоретико-методологічні підходи стосовно стресостійкості та факторів, що її обумовлюють, за доцільне у ході проведення емпіричного дослідження було обрано тестиопитувальники, спрямовані на вивчення рівню нервово-психічної стійкості та адаптивності до стресу, а також переважні копінг-стратегії студентів.

За нашим припущенням, у студентів, які навчаються за спеціальностями, пов'язаними із системою «людина-людина», показники стресостійкості мають бути менш вираженими. Професії гуманітарного профрілю пов'язані з більшим емоційним навантаженням. Об'єктом професійної діяльності такого фахівця є, насамперед, людина, із своїми психологічними особливостями, емоційним станом, рівнем агресивності, толерантності, що, відповідно, потребує від фахівця витримки та емоційної стабільності. Професії технічного напряму пов'язані переважно з роботою в системі «людина-техніка», що, в свою чергу, потребує від фахівця взаємодії з технічними засобами, у них простежується більш 
раціональний підхід у мисленні, тому, можна припустити, що показники стресостійкості студентів технічного спрямування будуть більш високими.

\section{III Результати}

Для перевірки гіпотези емпіричного дослідження було обрано валідний та надійний психодіагностичний інструментарій. Дослідження проводилося на базі Кременчуцького національного університету імені Михайла Остроградського. Кількість респондентів склала 40 осіб (16 дівчат та 24 хлопця), з яких 20 осіб - це студенти гуманітарних спеціальностей, що склали ЕГ1 та 20 осіб - технічних спеціальностей; вони склали ЕГ2.

На першому етапі дослідження було проведено методику «Копінг-поведінка в стресових ситуаціях» Ендлера-Паркера. Поняття «копінг» в психології вперше ввели Р. Лазарус і С. Фолкман в рамках транзактної моделі стресу [6]. Відповідно до цієї моделі, стрес і пережиті емоції є результатом взаємодії процесів середовища та людини. Згодом поняття «копінг» почало містити прийоми подолання не тільки з надмірними і перевищуючими ресурси людини вимогами, але й з повсякденними стресовими ситуаціями. Зміст поняття «копінг» при цьому залишилося без змін - це поведінкові когнітивні зусилля, що застосовуються індивідами для того, щоб адаптуватися до певних вимог в ситуаціях взаємодії людини і середовища [6].

А. Біллінгс і Р. Моос відзначають, що «копінг» обумовлений стійкими якостями особистості, що дозволяють використовувати певні варіанти відповіді на стресові ситуації. Саме ці якості визначають вибір поведінки людини в стресовій ситуації. Вони виділяють три способи подолання стресової ситуації: оцінка ситуації, втручання в ситуацію, уникнення [6; 7].

Р. Лазарус і С. Фолкман запропонували бінарну класифікацію копінг-стратегій, розділивши їх за спрямованістю: а) проблемно-фокусовані стратегії (11 копінгових дій); б) емоційно-фокусовані стратегії (62 копінгових дій) [6].

Р. Моос і Д. Шефффер виділили три види стратегій: 1) спрямовані на оцінку (встановлення значення ситуації для самого суб'єкта); 2) спрямовані на проблему (прийняття рішень і здійснення конкретних дій з метою подолання стресу); 3) спрямовані на емоції (управління почуттями і підтримка емоційного стану) [8]. Л. Перлин і С. Шулер пропонують аналогічну класифікацію, виділяючи в ній три наступні стратегії: 1) стратегія зміни способу бачення проблеми; 2) стратегія зміни проблеми; 3) стратегія управління емоціями [7].

Проаналізуємо результати даної методики (табл.1-2).

Табл. 1. Результати опитування ЕГ1 за типами копінг-стратегій

\begin{tabular}{|c|c|c|c|}
\hline \multirow{2}{*}{ Шкала } & \multicolumn{3}{|c|}{ Кількість респондентів } \\
\cline { 2 - 4 } & Низький рівень & Середній рівень & Високий рівень \\
\hline Проблемно-орієнтований копінг & 11 & 3 & 6 \\
\hline Емоційно-орієнтований копінг & 13 & 5 & 2 \\
\hline Уникнення & 6 & 7 & 7 \\
\hline Відволікання & 4 & 6 & 10 \\
\hline Соціальне відволікання & 7 & 5 & 8 \\
\hline
\end{tabular}

Табл. 2. Результати опитування ЕГ2 за типами копінг-стратегій

\begin{tabular}{|c|c|c|c|}
\hline \multirow{2}{*}{ Шкала } & \multicolumn{3}{|c|}{ Кількість респондентів } \\
\cline { 2 - 4 } & Низький рівень & Середній рівень & Високий рівень \\
\hline Проблемно-орієнтований копінг & 13 & 1 & 6 \\
\hline Емоційно-орієнтований копінг & 8 & 9 & 3 \\
\hline Уникнення & 12 & 3 & 5 \\
\hline Відволікання & 2 & 4 & 14 \\
\hline Соціальне відволікання & 3 & 10 & 7 \\
\hline
\end{tabular}


Відповідно до копінг-поведінки студентів гуманітарних спеціальностей були отримані наступні дані. Найбільші показники високого рівню було виявлено за шкалою «Відволікання» (50\%), що виявляється у перенесенні уваги на інші об'єкти діяльності, намаганні залишатися наодинці при виникненні стресової ситуації. Наступна шкала, яка має високий рівень прояву - це «Соціальне відволікання», що свідчить про те, що студенти у разі виникнення стресової ситуації намагаються відволіктися від неї за допомогою спілкування з іншими людьми. У таких студентів переважає прагнення виговоритися, поділитися своїми переживаннями з близькими людьми. Іноді вони можуть звертатися за порадами до інших. Такий варіант для студентів-гуманітаріїв, на наш погляд, $є$ більш прийнятним, адже їхні професії пов'язані із системою «людина-людина» і тому бажання отримати підтримку від інших, поділитися, знайти позитивний відгук є важливою рисою спеціаліста гуманітарних професій.

Низький рівень прояву було виявлено за шкалою «Емоційно-орієнтований копінг». $54 \%$ респондентів не приділяють увагу врегулюванню емоцій під час виникнення стресової ситуації, яскраво проявляють їх на зовні. Для фрахівців, які в майбутнього планують працювати з людьми, на наш погляд, це $є$ неприпустимим, особливо для студентів-психологів, адже це буде проявом їхньої професійної некомпетентності. Володіння власними емоціями, вміння їх приборкати, вчасно відслідкувати, усвідомити і застосувати необхідні засоби усунення негативних станів $€$ необхідною професійно важливою характеристикою фахівців, що обирають професії гуманітарного профілю. Тобто такий факт повинен залишатися в полі зору під час проведення корекційної роботи, мета якої полягає у необхідності розвинення у студентів складових емоційного інтелекту, навчити їх навичкам регулювання емоційних станів, надавати практичні інструменти для конструктивного виходу емоцій.

За шкалою «Проблемно-орієнтований копінг» у 55\% виявлено низький рівень, тобто більшість студентів-гуманітаріїв не використовують стратегію зосередження на проблемі, іï аналізі, плануванні дій виходу з проблемної ситуації; це також варто враховувати при плануванні програми психокорекційних впливів.

У студентів технічних спеціальностей високий рівень поведінкових стратегій щодо подолання стресових ситуацій виявлено за шкалою «Відволікання», тобто 70\% мають високий рівень прояву такої стратегії, що виявляється у перенесенні уваги на інші об'єкти діяльності, намаганні побути наодинці, зайнятись творчістю та ін.

Натомість низькі показники отримано, як і в ситуації із студентами-гуманітаріями, за шкалою «Проблемно-орієнтований копінг» та «Уникнення». Переважаючий низький рівень за цією шкалою свідчить про низьку здатність вирішувати проблеми самостійно. Низький рівень прояву копінгу, спрямованого на уникнення, характеризується тим, що студенти у разі виникнення стресової ситуації не уникають проблеми, а намагаються навпаки знайти певне її рішення.

Отже, можна констатувати, що студентам технічних спеціальностей (ЕГ2) притаманне використання таких копінг-стратегій як: відволікання, соціальне відволікання та уникнення, тоді як студентам-гуманітаріям властиве використання емоційно-орієнтованого копінгу. Студенти гуманітарної спеціальності фокусуються на врегулюванні емоційної реакції під час стресової ситуації. Така особливість для студентів технічної спрямованості не притаманна, адже вони переважно уникають проблем, відволікаються від них або переключаються на інші види діяльності. Водночас, у студентів гуманітарної та технічної спрямованості значно виражений низький рівень проблемно-орієнтованого копінгу, що свідчить про відсутність орієнтації на вирішення проблем, низький рівень аналізу причин їх виникнення. Такі студенти не намагаються вирішувати проблеми самостійно і цей аспект потрібно враховувати фрахівцям психологічної служби навчальних закладів, впроваджуючи психологічні програми профрілактики щодо підвищення стресостійкості.

Наступний етап емпіричного дослідження передбачав проведення методики «Адаптивність до стресу «АС» (В.М. Розова), результати якої дозволяють з'ясувати рівень адаптованості до різноманітних стресових ситуацій, що мають студенти різної профресійної спрямованості. Проаналізуємо результати методики (табл. 3).

Проблема соціальної адаптації - одна з ключових у сучасних дослідженнях психології особистості. Насамперед тут конкретизується об'єкт адаптації - безупинне й активне пристосування людини до умов соціального середовища [9]. Адаптація - це пристосування людини як особистості до існування в суспільстві відповідно до вимог цього суспільства і з власними потребами, мотивами й 
інтересами. Загальновизнано адаптація розуміється як процес пристосування людини до мінливих умов зовнішнього середовища, як статико-динамічне явище, що розвертається від моменту ознайомлення людини з новими умовами існування до вироблення адекватної адаптивної реакції. Процес адаптації здійснюється як взаємодія людини з зовнішнім середовищем, у ході чого за рахунок визначених змін суб'єкта формується адаптивна реакція. Характер адаптивних змін залежить від швидкості й інтенсивності впливу того чи іншого фактора середовища.

Табл. 3. Порівняння результатів ЕГ1 та ЕГ2 за рівнем адаптивності до стресу

\begin{tabular}{|c|c|c|c|}
\hline \multirow{2}{*}{ Групи студентів } & \multicolumn{3}{|c|}{ Рівень адаптивності до стресу, \% } \\
\cline { 2 - 4 } & низький & середній & високий \\
\hline ЕГ1 & 70 & 20 & 10 \\
(студенти гуманітарних спеціальностей) & & & \\
\hline $\begin{array}{c}\text { ЕГ2 } \\
\text { (студенти технічних спеціальностей) }\end{array}$ & 20 & 30 & 50 \\
\hline
\end{tabular}

За результатами дослідження рівню адаптованості до стресу виявлено, що 10\% респондентів гуманітарних спеціальностей мають високий рівень адаптивності до стресу, однак респонденти технічних спеціальностей мають більш виражений показник, що становить 50\%. Це свідчить про те, що студенти технічного профрілю навчання більш адаптовані до стресів на відміну від студентів гуманітарного профілю. Середній рівень у студентів гуманітарної спрямованості становить 20\%, а у студентів технічної спрямованості - 30\%. Низький рівень спостерігається у $70 \%$ респондентів гуманітарних спеціальностей та 20\% у респондентів технічних спеціальностей. Такі дані, можливо, будуть пов'язані з об'єктами майбутньої професійної діяльності, адже об'єктом майбутньої професійної діяльності студентів технічних спеціальностей буде система «людина-техніка», тоді як студентів гуманітарної спрямованості - «людина-людина», що вимагає більшої емоційної напруги, відповідального ставлення до фізичного та психологічного стану людини з якою необхідно буде працювати. Під час навчання студенти гуманітарних спеціальностей мають недостатню практичну підготовку і тому, ймовірно, можуть мати підвищену тривожність та страхи відносно безпосередньої взаємодії з об'єктами майбутньої професійної діяльності.

На третьому етапі дослідження було проведено анкету оцінки нервово-психічної стійкості «Прогноз» В. Ю. Рибнікова. Результати дослідження подано у таблиці 4.

Табл. 4. Порівняння результатів ЕГ1 та ЕГ2 за типами прогнозу нервово-психічної стійкості

\begin{tabular}{|c|c|c|}
\hline \multirow{2}{*}{ Групи } & \multicolumn{2}{|c|}{ Тип нервово-психічної стійкості, \% } \\
\cline { 2 - 3 } & сприятливий & несприятливий \\
\hline ЕГ1 & 40 & 60 \\
(студенти гуманітарних спеціальностей) & & 30 \\
\hline ЕГ2 & 70 & \\
(студенти технічних спеціальностей) & & \\
\hline
\end{tabular}

За результатами анкети 40\% респондентів гуманітарних спеціальностей мають сприятливий нервово-психічний прогноз, тоді як у студентів технічних спеціальностей цей показник складає 70\%. Це свідчить про низьку адаптацію студентів-гуманітаріїв до стресових факторів, схильність до нервових зривів. Респонденти технічних спеціальностей більш адаптовані до впливу стресових факторів. Сприятливий прогноз нервово-психічної стійкості вказує на низьку вірогідність нервових зривів, високу здатність протистояти дії стресогених чинників та нервовому напруженню.

\section{IV Обговорення}

Отже, стресостійкість студентів визначається можливістю протистояти дії стресогенних факторів у студентському середовищі, як то ситуації іспитів, періоди соціальної адаптації, необхідності постійного особистісного вдосконалення, нестача часу для підготовки до занять, думки про працевлаштування 
наприкінці навчання, розчарування в обраній професій, невідповідність очікувань та реальності тощо. Таким чином, постійний стан стресу і його наслідки становлять серйозну загрозу психічному здоров'ю студентів. Проведене дослідження показало, що студенти різних професійних спрямувань мають властиві для них особливості розвитку та прояву стресостійкості, пов'язані з різними об'єктами майбутньої професійної діяльності, різними освітніми програмами підготовки, різною кількістю годин, що виділяються на практичну підготовку, а також індивідуально-психологічними особливостями самих студентів. 3 метою профілактики стресових ситуацій та розвитку стресостійкості, студентам під час навчання необхідно впроваджувати програми психологічного впливу, тренінгові заняття, що будуть містить вправи, спрямовані на розвиток емпатійних якостей, на профрілактику агресивних та негативних проявів, на зняття емоційної напруги, на релаксацію.

\section{V Висновки}

Отже, результати дослідження показали, що висунута нами гіпотеза, стосовно більш високої чутливості до стресових станів студентів гуманітарних спеціальностей підтвердилась. Вони більш емоційно реагують на ситуацію невизначеності, що є атрибутом сучасного соціального простору, у тому числі й освітнього. Нервово-психічна стійкість більш виражена у студентів технічних спеціальностей. Цей факт, можливо, пов'язаний з тим, що існує певний гендерний дисбаланс в контингенті студентів цих двох видів професій - технічні спеціальності більше обирають хлопці, тоді як гуманітарні спеціальності дівчата, а вони більш емоційно вразливі. Хлопці ж у ситуаціях стресу схильні до використання аналітичного мислення під час розгляду певних обставин, намагаються зрозуміти причини їх виникнення, тобто підходять до вирішення проблеми більш раціонально. Утім, цей висновок потребує у подальшому більш детальної емпіричної перевірки.

Перспективними напрямами наступних досліджень вбачаємо вивчення гендерного аспекту означеної проблеми, дослідження впливу індивідуально-психологічних властивостей студентів на рівень їхньої стресостійкості, а також розробку та апробацію науково обґрунтованої програми психокорекційних впливів щодо розвитку стресостійкості у студентів різних спеціальностей.

\section{Бібліографічні посилання}

[1] Розов В. І. Адаптивні антистресові психотехнології. К. : Кондор, 2005. 278 с.

[2] Сергеев С.И. Стресс в организациях социальной сфреры: причины, профилактика, противодействие // Мир психологии. 2002. № 4. С. 245-250.

[3] Баранов А А. Психологическая стрессоустойчивость и мастерство педагога: теоретические и прикладные аспекты : авторефр. дис. на здобуття наук. ступеня д-ра психол. наук. СПб, 2002. 41 с.

[4] Падун М. Когнитивно-личностные аспекты переживания посттравматического стресса // Психологический журнал. 2004. № 5. C. 5-16.

[5] Павленко В.М. Психогенні розлади як наслідок дії екстремальних умов на особистість // Актуальні проблеми психології: зб. наук. праць Інституту психології ім. Г.С. Костюка АПН України / за ред. С. Д. Максименка. К. : ДП «ннформаційно-аналітичне агенство», 2004. Т. V. вип. 3. С. 105-111.

[6] Судаков К. В. Индивидуальная устойчивость к стрессу. М. : Аспект-пресс, 1998. С. 3-168.

[7] Съедин С.И. Некоторые пути преодоления негативного влияния стрессовых ситуаций на состояние психического здоровья // Мир психологии. 2002. № 4. С. 235-244.

[8] Стрес і його роль в житті людини. Адаптація і стрес // Психологічне забезпечення психічного і фрізичного здоров'я. К. : Кондор, 2002. С. 227-260.

[9] Завацька Н. Є. Аналіз підходів до проблеми соціально-психологічної дезадаптації особистості // Теоретичні $i$ прикладні проблеми психології, 2004. №1(6). С.84-88.

\section{References}

[1] Rozov, V. I. (2005). Adaptivni antistresovi psikhotekhnologii [Adaptive anti-stress psychotechnologies]. K. : Kondor [in Ukrainian].

[2] Sergeev, S. I. (2002). Stress v organizatsiyakh sotsialnoy sfery: prichiny, profilaktika, protivodeystvie [Stress in social organizations: causes, prevention, counteraction]. Mir psikhologii - World of psychology, 4, 245-250 [in Russian].

[3] Baranov, A. A. (2002). Psikhologicheskaya stressoustoychivost i masterstvo pedagoga: teoreticheskie i prikladnye aspekty [Psychological stress tolerance and mastery of the teacher: theoretical and applied aspects]. Extended abstract of candidate's thesis. SPb [in Russian]. 
[4] Padun M., (2004). Kognitivno-lichnostnye aspekty perezhivaniya posttravmaticheskogo stressa [Cognitive-personal aspects of experiencing post-traumatic stress]. Psikhologicheskiy zhurnal - Psychological Journal, 5, 5-16. [in Russian].

[5] Pavlenko, V. M. (2004Psikhogenni rozladi yak naslidok diï ekstremalnikh umov na osobistist, S. D. Maksimenko (Eds.) [Psychogenic disorders as a result of the action of extreme conditions on the person], Aktualni problemi psikhologiï: zb. nauk. prats Institutu psikhologiï im. G.S. Kostyuka APN Ukraïni (Vols. V) - Actual problems of psychology, (pp. 105-111), K. : DP «Informatsiyno-analitichne agenstvo» [in Ukrainian].

[6] Sudakov, K. V. (1998). Individualnaya ustoychivost k stress [Individual resistance to stress]. M. : Aspekt-press [in Russian].

[7] Sedin, S. I. (2002). Nekotorye puti preodoleniya negativnogo vliyaniya stressovykh situatsiy na sostoyanie psikhicheskogo zdorovya [Some ways to overcome the negative impact of stressful situations on mental health]. Mir psikhologii - World of psychology, 4, 235-244 [in Russian].

[8] Stres i yogo rol v zhitti lyudini. Adaptatsiya i stress [Stress and his role in human life. Adaptation and stress] (2002). Psikhologichne zabezpechennya psikhichnogo i fizichnogo zdorov'ya [Psychological support for mental and physical health] (pp 227-260). K. : Kondor [in Ukrainian].

[9] Zavatska, N. Є. (2002). Analiz pidkhodiv do problemi sotsialno-psikhologichnoï dezadaptatsiï osobistosti [Analysis of approaches to the problem of socio-psychological maladaptation of the individual]. Teoretichni i prikladni problemi psikhologiil - Theoretical and applied problems of psychology, 1(6), 84-88.

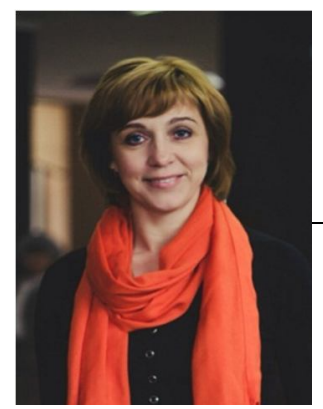

\section{Літвінова Ольга Володимирівна,}

Канд. психол. наук, доцент, доцент кафедри психології, педагогіки та філософії, Кременчуцький національний університет імені Михайла Остроградського, вул. Першотравнева, 20, м. Кременчук Полтавської обл., Україна, 39600.

Тел. 38(050) 913-15-23. E-mail: : litvinova1992@gmail.com

\section{Litvinova Olga Volodymyrivna,}

Cand. Sc. (Psychol.), Associate Professor, Associate Professor of Pedagogy and Philosophy Department, Kremenchuk Mykhailo Ostrohradskyi National University,

vul. Pershotravneva, 20, Kremenchuk, Poltava Region, Ukraine, 39600.

Тел. 38(050) 913-15-23. E-mail: : litvinova1992@gmail.com

ORCID: 0000-0001-5261-6358

Researcher ID:U-7624-2017

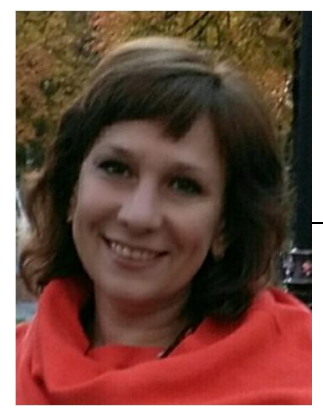

\section{Федоренко Світлана Анатоліївна.}

Канд .і. наук, доцент, доцент кафедри психології, педагогіки та філософії, Кременчуцький національний університет імені Михайла Остроградського, вул. Першотравнева, 20, м. Кременчук Полтавської обл., Україна, 39600. Тел. +38(066) 780-85-03. E-mail: svfedor70@gmail.com

\section{Fedorenko Svitlana Anatoliyivna,}

Cand. Sc. (Histor.), Associate Professor, Associate Professor of Pedagogy and Philosophy Department, Kremenchuk Mykhailo Ostrohradskyi National University, vul. Pershotravneva, 20, Kremenchuk, Poltava Region, Ukraine, 39600.

Tel.+ 38(066) 780-85-03. E-mail: svfedor70@gmail.com

ORCID: 0000-0002-6999-4926

\section{Citation (APA):}

Litvinova, O., Fedorenko, S. (2019). Empirical indicators of the level of stress resistance in students of humanitarian and technical specialties. Engineering and Educational Technologies, 7 (2), 181-189. doi: https://doi.org/10.30929/2307-9770.2019.07.02.18

\section{Цитування (ДСТУ 8302:2015):}

Літвінова О. В., Федоренко С. А. Емпіричні показники рівню стресостійкості у студентів гуманітарних та технічних напрямів навчання / Інженерні та освітні технології. 2019. Т. 7. № 2. С. 181-189. doi: https://doi.org/10.30929/2307-9770.2019.07.02.18

Обсяг статmі: $\quad$ сторінок - 9 ; умовних друк. аркушів - 1,304. 